\title{
PENGGUNAAN PENDEKATAN KONTEKSTUAL MELALUI MEDIA SIMULASI ANIMASI KOMPUTER DAN FILM PENDEK DITINJAU DARI KEMAMPUAN PENALARAN ANALITIS DAN GAYA BELAJAR SISWA
}

\author{
Anggit Grahito Wicaksono $^{11}$, Sarwanto $^{12}$, Suparmi ${ }^{2}$ \\ ${ }^{1}$ Mahasiswa Program Studi Pendidikan Sains Program Pascasarjana Universitas Sebelas Maret \\ gara_hito@yahoo.co.id \\ ${ }^{2}$ Dosen Program Studi Pendidikan Sains Program Pascasarjana Universitas Sebelas Maret \\ sar1to@yahoo.com \\ ${ }^{3}$ Dosen Program Studi Pendidikan Sains Program Pascasarjana Universitas Sebelas Maret \\ suparmiuns@gmail.com
}

\begin{abstract}
ABSTRAK
Penelitian ini bertujuan untuk mengetahui pengaruh dan interaksi antara penggunaan pendekatan kontekstual melalui media simulasi animasi komputer dan film pendek, kemampuan penalaran analitis, dan gaya belajar siswa terhadap prestasi belajar siswa. Penelitian menggunakan metode kuasi eksperimen dan dilaksanakan di SMK Muhammadiyah 4 Sragen pada kelas XI TKJ (Teknik Komputer dan Jaringan) Tahun Ajaran 2012/ 2013 terdiri dari 3 kelas. Teknik pengambilan sampel menggunakan cluster random sampling. Sampel sebanyak 2 kelas, kelas XI TKJ 1 sebagai kelas eksperimen I mendapatkan perlakuan pembelajaran dengan pendekatan kontekstual melalui media simulasi animasi komputer dan kelas XI TKJ 2 sebagai kelas eksperimen II mendapatkan perlakuan pembelajaran dengan pendekatan kontekstual melalui media film pendek. Data diperoleh melalui teknik tes untuk prestasi kognitif, kemampuan penalaran analitis, angket gaya belajar, dan lembar observasi untuk prestasi afektif. Teknik analisis data menggunakan ANAVA tiga jalan dengan General Linier Model (GLM) melalui program SPSS versi 16. Hasil penelitian menunjukkan: (1) ada pengaruh penggunaan pendekatan kontekstual melalui media simulasi animasi komputer dan film pendek terhadap prestasi belajar siswa; (2) ada pengaruh kemampuan penalaran analitis terhadap prestasi belajar siswa; (3) ada pengaruh gaya belajar terhadap prestasi belajar siswa; (4) ada interaksi antara penggunaan pendekatan kontekstual melalui media simulasi animasi komputer dan film pendek dengan kemampuan penalaran analitis siswa terhadap prestasi belajar siswa; (5) tidak ada interaksi antara penggunaan pendekatan kontekstual melalui media simulasi animasi komputer dan film pendek dengan gaya belajar siswa terhadap prestasi belajar siswa; (6) ada interaksi antara kemampuan penalaran analitis dan gaya belajar siswa terhadap prestasi belajar siswa; (7) tidak ada interaksi antara penggunaan pendekatan kontekstual melalui media simulasi animasi komputer dan film pendek, kemampuan penalaran analitis dan gaya belajar siswa terhadap prestasi belajar siswa.
\end{abstract}

Kata Kunci : Pendekatan kontekstual, simulasi animasi komputer, film pendek, kemampuan penalaran analitis, gaya belajar 


\section{PENDAHULUAN}

Pendidikan pada dasarnya merupakan suatu upaya untuk memberikan pengetahuan, wawasan, keterampilan dan keahlian tertentu pada individuindividu guna mengembangkan bakat serta kepribadian manusia. Dengan pendidikan manusia berusaha mengembangkan dirinya sehingga mampu menghadapi setiap perubahan yang terjadi akibat adanya kemajuan ilmu pengetahuan dan teknologi. Oleh karena itu masalah pendidikan perlu mendapat perhatian dan penanganan serius yang menyangkut berbagai masalah yang berkaitan dengan kuantitas, kualitas dan relevansinya.

Beberapa masalah yang cukup mengkhawatirkan dari pendidikan di Indonesia terutama dalam bidang Matematika dan Sains terungkap dari hasil TIMSS. Indonesia berada di papan bawah dibandingkan dengan beberapa negara di Asia. Nilai rata-rata skor prestasi Sains siswa Indonesia pada TIMSS tahun 1999, 2003, dan 2007 secara berurutan adalah 435, 420, dan 433. Dengan perolehan skor tersebut siswa Indonesia menempati peringkat 32 dari 38 negara (1999), peringkat 37 dari 46 negara (2003), dan peringkat 35 dari 49 negara (2007). Soal-soal TIMSS cenderung untuk mengungkap produk, proses, dan sikap. Padahal pembelajaran Sains di Indonesia belum sampai untuk mengungkap proses hanya diunggulkan dalam produk dan sikap saja. Walaupun tim olimpiade Sains Indonesia lebih unggul dibandingkan Singapura maupun Malaysia tetapi hal itu tidak menjamin hasil TIMSS menjadi lebih baik. Kemampuan penalaran dan logika siswa-siswa di Indonesia masih sangat terbatas sehingga hasil TIMSS menjadi lebih buruk lagi. Dengan hasil perolehan tersebut, rata-rata siswa Indonesia hanya mampu mengenali sejumlah fakta dasar tetapi belum mampu mengkomunikasikan dan mengaitkan berbagai topik sains, apalagi menerapkan konsepkonsep yang kompleks dan abstrak.

Pada saat ini berkembang pemikiran dikalangan para ahli pendidikan bahwa anak akan belajar lebih baik jika lingkungan diciptakan ilmiah yaitu siswa diibaratkan seperti ilmuwan yang menemukan konsep mereka sendiri dan memecahkan masalah mereka dengan analisis mereka masing-masing. Belajar akan lebih bermakna jika anak mengalaminya, bukan hanya mengetahui saja. Anggapan-anggapan bahwa Fisika itu sulit karena objek materi Fisika yang cenderung abstrak dan penurunan rumus yang rumit, ditambah lagi penyajiannya dengan pendekatan yang konvensional. Dalam belajar Fisika di sekolah terutama Sekolah Menengah Kejuruan (SMK) tidak sedikit siswa yang tidak dapat menangkap konsep Fisika, siswa cenderung lebih banyak menghafal saja karena pada Sekolah Menengah Kejuruan (SMK) hanya berfungsi sebagai mata pelajaran pendukung kompetensi program keahliannya. Inilah yang menyebabkan rendahnya kemampuan Fisika siswa.

Sekarang pendidikan di Indonesia mengenal banyaknya pendekatan pembelajaran dalam proses belajar mengajar. Pendekatanpendekatan tersebut antara lain pendekatan konsep, pendekatan konstruktivistik, pendekatan kooperatif, pendekatan kontekstual, pendekatan pembelajaran berbasis masalah, dan sebagainya. Dalam memilih pendekatan pembelajaran harus disesuaikan dengan karakteristik materi dan perkembangan kognitif, agar pengintegrasian pengetahuan dapat diperoleh peserta didik.

Salah satu yang berkembang sekarang adalah pendekatan kontekstual (contextual teaching and learning). Menurut Nurhadi yang dikutip oleh Sugiyanto (2007: 1) "pembelajaran kontekstual adalah konsep yang mendorong guru untuk menghubungkan antara materi yang diajarkan dan situasi dunia nyata siswa." Pengetahuan dan keterampilan siswa diperoleh dari usaha siswa mengkonstruksi sendiri pengetahuan dan keterampilan baru ketika siswa belajar. Pembelajaran kontekstual menerapkan tujuh komponen utama yakni konstruktivisme, bertanya, menemukan, masyarakat belajar, pemodelan, refleksi, dan penilaian sebenarnya.

Pada masa lalu, proses belajar mengajar lebih menekankan pada pengajaran dari pada pembelajaran. Menurut J.J Hasibuan dan Moedjiono (2006: 37) "konsep mengajar dalam proses perkembangannya masih dianggap sebagai suatu kegiatan penyampaian atau penyerahan pengetahuan." Sehingga siswa belajar Fisika hanya dengan cara menghafal dan sekedar mengingat rumus. Mengingat keabstrakan Fisika, pada dasarnya belajar Fisika merupakan belajar proses bukan hanya sekedar konsep. Pendekatan kontekstual menyajikan suatu konsep yang mengaitkan materi pelajaran yang dipelajari siswa dengan konteks kehidupan sehari-hari mereka. Konteks memberi arti, relevansi dan manfaat penuh terhadap belajar. Dengan mengetahui manfaat/kegunaan materi pelajaran, 
maka siswa akan bertanggung jawab dalam belajar.

Widodo (2009) dari prodi Pendidikan Sains minat utama Kimia dalam penelitiannya menyimpulkan bahwa ada perbedaan pengaruh penggunaan pendekatan kontekstual melalui metode eksperimen dan demonstrasi terhadap prestasi belajar kimia siswa. Penelitian yang sejenis yang dilakukan oleh Kokom Komalasari (2009) menyimpulkan bahwa "contextual learning in civic education influenced positively and significantly and contributed $26 \%$ to the civic competence of Junior High School student." Jadi dari penelitian-penelitian tersebut menyatakan bahwa pembelajaran kontekstual berpengaruh positif dan signifikan terhadap prestasi belajar.

Walaupun Fisika hanya pendamping untuk kompetensi program keahlian, tetapi harus dapat menjadi dasar yang kuat guna mendukung kompetensi program keahliannya. Maka perlu adanya peningkatan kualitas pembelajaran dengan menggunakan media penunjang pembelajaran. Simulasi animasi komputer dan film pendek pada Tesis ini merupakan contoh media penunjang pembelajaran. Kedua media tersebut sangat berkaitan erat dengan perkembangan teknologi informasi sehingga sesuai dengan kompetensi program keahlian Teknik Komputer dan Jaringan (TKJ). "Media pembelajaran adalah sesuatu yang dapat mengantarkan pesan pembelajaran antara pemberi pesan kepada penerima pesan" (Sri Anitah, 2008:1). Gagne dan Briggs dalam Azhar Arsyad secara implisit mengatakan bahwa "media pembelajaran meliputi alat yang secara fisik digunakan untuk menyampaikan isi materi pengajaran, yang terdiri dari antara lain buku, tape recorder, kaset, video camera, video recorder, film, slide, foto, gambar, grafik, televisi dan komputer" (2002: 4). Jadi dengan adanya media pembelajaran akan dapat memudahkan guru untuk menyampaikan pesan/informasi kepada peserta didik dengan lebih jelas, menarik dan inovatif.

Widha Sunarno (2008) dalam penelitiannya dalam Jurnal Paedogogia Pendidikan menyimpulkan bahwa pembelajaran menggunakan media komputer lebih efektif dibandingkan pembelajaran menggunakan media audio-visual dan pembelajaran menggunakan media konvensional. Penelitian sejenis yang dilakukan oleh Murwani Dewi Wijayanti (2009) menyimpulkan bahwa prestasi belajar kimia hasil dari penerapan model pembelajaran individual dengan media modul berbasis IT lebih sesuai dari pada model pembelajaran individual dengan simulasi animasi komputer. Jadi dari penelitian penelitian tersebut menyatakan bahwa penggunaan media pembelajaran berbasis komputer akan lebih berpengaruh signifikan dibandingkan mengunakan media konvensional dalam pembelajaran di sekolah.

Keberhasilan belajar siswa dipengaruhi oleh banyak faktor, baik dari dalam diri (internal) maupun faktor lingkungan (eksternal). Dimyati dan Mudjiono (1999: 238) menyatakan bahwa "faktor internal adalah faktor yang berasal dari dalam diri siswa, baik yang berupa fisik maupun mental misalnya kecerdasan, minat, bakat, konsentrasi dan lain sebagainya. Sedangkan faktor eksternal adalah faktor yang datang dari luar diri anak, seperti; metode, kurikulum, keadaan keluarga dan lingkungan, disiplin sekolah, serta sarana dan prasarana sekolah. Namun pada kenyataannya, faktor internal siswa cenderung kurang diperhatikan dalam proses pembelajaran. Untuk itu perlu adanya wacana terhadap gaya belajar siswa dan kemampuan analitis siswa.

Salah satu faktor yang dapat mempengaruhi hasil belajar adalah kemampuan penalaran analitis. Kemampuan tersebut bertujuan untuk mengukur kemampuan membaca, mencerna, menganalisis, dan menarik kesimpulan logis dan metodis terhadap informasi yang diberikan (Anonim, 2009: 2). Kemampuan ini menuntut peserta didik belajar memecahkan soal berdasarkan informasi yang disajikan. Ciri yang pertama adalah adanya suatu pola berpikir yang secara luas dapat disebut logika, dan tiap penalaran mempunyai logika tersendiri atau dapat juga disimpulkan bahwa kegiatan penalaran merupakan suatu kegiatan berpikir logis, dimana berpikir logis disini harus diartikan sebagai kegiatan berpikir menurut suatu pola tertentu atau logika tertentu. Ciri yang kedua dari penalaran adalah sifat analitik dari proses berpikirnya. Penalaran merupakan suatu kegiatan berpikir yang menandarkan diri kepada suatu analisis dan kerangka berpikir yang digunakan untuk analisis tersebut adalah logika penalaran yang bersangkutan. Artinya penalaran ilmiah merupakan kegiatan analisis yang mempergunakan logika ilmiah, dan demikian juga penalaran lainnya yang mempergunakan 
logikanya tersendiri. Sifat analitik ini merupakan konsekuensi dari suatu pola berpikir tertentu.

Murwani Dewi Wijayanti (2009) dalam penelitiannya menyimpulkan bahwa media modul berbasis IT pada model pembelajaran individual lebih sesuai untuk prestasi belajar peserta belajar yang memiliki daya kemampuan penalaran analitis tinggi dibandingkan kemampuan penalaran analitis rendah. Jadi dari penelitian tersebut menyatakan bahwa kemampuan penalaran analitis berpengaruh signifikan terhadap prestasi belajar siswa.

Disamping kemampuan penalaran analitis, faktor lain yang dapat mempengaruhi prestasi belajar siswa adalah gaya belajar. Gaya belajar siswa merupakan cara yang khas dan konsisten oleh siswa dalam menyerap informasi. Gaya belajar siswa dikelompokkan menjadi tiga tipe yaitu visual, auditorial, dan kinestetik. Pada umumnya siswa memiliki ketiga gaya belajar tersebut, namun ada satu yang paling dominan dimilkinya. Kebanyakan siswa belum mengenal persis gaya belajar yang dimilikinya sehingga akan lebih mudah menerima materi yang disajikan dengan diskusi dan tanya jawab. Komponen startegi pembelajaran kontekstual yaitu bertanya dan masyarakat belajar dapat membantu siswa auditorial. Gaya belajar visual menggunakan indera penglihatannya untuk membantunya belajar. Dalam pembelajaran kontekstual digunakan sesuatu yang nyata, sesuatu yang sudah diketahui siswa untuk menyampaikan materi sehingga siswa visual dapat dibantu dengan membawa alat peraga seperti gambar, flow chart. Gaya belajar kinestetik menggunakan fisiknya sebagai alat belajar yang optimal. Siswa kinestetik dibantu dengan membawa alat peraga yang nyata misal balok, patung, ataupun dengan media komputer. Untuk itu gaya belajar merupakan komponen penting dalam mengaktualisasikan kemampuan belajar siswa.

Teguh Ernawan (2010) dalam penelitiannya menyimpulkan bahwa tidak ada pengaruh yang signifikan dari prestasi belajar siswa yang memiliki gaya belajar baik visual, auditorial, maupun kinestetik. Penelitian yang sejenis yang dilakukan Basir (2010) menyimpulkan bahwa gaya belajar merupakan variabel penting yang perlu dipertimbangkan dalam proses pembelajaran untuk meningkatkan prestasi belajar siswa. Jadi dari penelitianpenelitian tersebut menyatakan bahwa gaya belajar siswa itu berpengaruh signifikan terhadap prestasi belajar siswa.

Dalam melaksanakan belajar dikenal beberapa macam teori belajar, antara lain: teori belajar asosiasi, ilmu jiwa daya, teori belajar Gestalt dan sebagainya. Penelitian ini membahas tentang pengajaran Fisika, maka teori yang sesuai adalah teori belajar Ausubel, teori belajar Gagne, teori belajar Piaget, dan teori belajar Bruner. Dalam menerapkan media pembelajaran dan metode pengajaran, hendaknya dapat menggunakan media yang menarik, efektif, dan interaktif sesuai pokok bahasan dalam Fisika yang mana memiliki karakteristik-karakteristik sendiri. Mata pelajaran Fisika merupakan mata pelajaran adaptif, yang bertujuan membekali peserta didik dasar pengetahuan tentang hukumhukum kealaman yang penguasaannya menjadi dasar sekaligus syarat kemampuan yang berfungsi mengantarkan peserta didik guna mencapai kompetensi program keahliannya. Di samping itu mata pelajaran Fisika mempersiapkan peserta didik agar dapat mengembangkan program keahliannya pada tingkat pendidikan yang lebih tinggi. Penguasaan mata pelajaran Fisika memudahkan peserta didik menganalisis proses-proses yang berkaitan dengan dasar-dasar kinerja peralatan dan piranti yang difungsikan untuk mendukung pembentukan kompetensi program keahlian. Sesuai dengan Garis-Garis Besar Program Pengajaran (GBPP) Sekolah Menengah Kejuruan (SMK) Kurikulum Tingkat Satuan Pendidikan dan Suplemennya berdasarkan sistem semester, pokok bahasan Suhu dan Kalor diberikan pada siswa SMK kelompok teknologi dan kesehatan kelas XI semester I. Pokok bahasan Suhu dan Kalor ini memiliki karakteristik yang konkret dan sering dijumpai dalam kehidupan sehari-hari peserta didik sehingga sesuai dengan pendekatan kontekstual yang mengunggulkan pembelajaran sesuai dengan konteks kehidupan sehari-hari.

Penelitian ini bertujuan untuk mengetahui: (1) pengaruh penggunaan media simulasi animasi komputer dan film pendek terhadap prestasi belajar siswa pada pokok bahasan Suhu dan Kalor; (2) pengaruh kemampuan penalaran analitis tinggi dan rendah terhadap prestasi belajar siswa pada pokok bahasan Suhu dan Kalor; (3) pengaruh gaya belajar visual dan kinestetik terhadap prestasi belajar siswa pada pokok bahasan Suhu dan Kalor; (4) interaksi antara penggunaan media 
ISSN: 2252-7893, Vol 2, No 12013 (hal 55-65)

http://jurnal.fkip.uns.ac.id/index.php/sains

pembelajaran dan kemampuan penalaran analitis terhadap prestasi belajar siswa pada pokok bahasan Suhu dan Kalor; (5) interaksi antara penggunaan media pembelajaran dan gaya belajar terhadap prestasi belajar siswa pada pokok bahasan Suhu dan Kalor; (6) interaksi antara kemampuan penalaran analitis dan gaya belajar terhadap prestasi belajar siswa pada pokok bahasan Suhu dan Kalor; (7) interaksi antara penggunaan media pembelajaran, kemampuan penalaran analitis, dan gaya belajar terhadap prestasi belajar siswa pada pokok bahasan Suhu dan Kalor.

\section{METODE PENELITIAN}

Penelitian menggunakan metode kuasi eksperimen. Penelitian dilaksanakan di SMK Muhammadiyah 4 Sragen. Populasi semua siswa kelas XI TKJ (Teknik Komputer dan Jaringan) Tahun Ajaran 2012/ 2013 terdiri dari 3 kelas. Teknik pengambilan sampel menggunakan cluster random sampling. Sampel sebanyak 2 kelas, kelas XI TKJ 1 sebagai kelas eksperimen I mendapatkan perlakuan pembelajaran dengan pendekatan kontekstual melalui media simulasi animasi komputer dan kelas XI TKJ 2 sebagai kelas eksperimen II mendapatkan perlakuan pembelajaran dengan pendekatan kontekstual melalui media film pendek. Pengambilan data melalui teknik tes untuk mengetahui prestasi kognitif dan kemampuan penalaran analitis. Teknik angket untuk mengetahui gaya belajar, dan lembar observasi untuk mengamati kemampuan afektif. Sebagai prasyarat analisis data, yaitu uji normalitas dengan KolmogorovSmirnov melalui Uji Lilliefors dan uji homogenitas dengan Uji Levene. Teknik analisis data menggunakan ANAVA tiga jalan dengan General Linier Model (GLM) melalui program SPSS versi 16.

\section{HASIL PENELITIAN DAN PEMBAHASAN}

Deskripsi data sebaran presasi belajar disajikan dalam Tabel 1a. dan Tabel 1b.

Tabel 1a. Data Sebaran Prestasi Belajar Kognitif

\begin{tabular}{ccc}
\hline & \multicolumn{2}{c}{ Media } \\
\hline & $\begin{array}{c}\text { Simulasi } \\
\text { Animasi }\end{array}$ & Film Pendek \\
\hline Jml Data & 38 & 38 \\
\hline Mean & 66,684 & 69,210 \\
\hline SD & 6,854 & 7,197 \\
\hline
\end{tabular}

Tabel 1b. Data Sebaran Prestasi Belajar Afektif

\begin{tabular}{ccc}
\hline & \multicolumn{2}{c}{ Media } \\
\hline & $\begin{array}{c}\text { Simulasi } \\
\text { Animasi }\end{array}$ & Film Pendek \\
\hline Jml Data & 38 & 38 \\
\hline Mean & 68,421 & 72,368 \\
\hline SD & 10,973 & 10,763 \\
\hline
\end{tabular}

Adapun untuk rangkuman anava tiga jalan terhadap prestasi belajar kognitif disajikan dalam Tabel 2a dan Tabel 2b

Tabel 2a. Rangkuman Uji Hipotesis Prestasi Belajar

\begin{tabular}{|c|c|c|c|}
\hline \multirow{2}{*}{ No } & \multirow{2}{*}{ Variabel } & \multicolumn{2}{|c|}{ Prestasi Belajar Kognitif } \\
\hline & & Sig. & Keputusan Uji \\
\hline 1. & Media & 0.002 & $\mathrm{H}_{0}$ ditolak \\
\hline 2. & $\begin{array}{l}\text { Kemampuan Penalaran } \\
\text { Analitis }\end{array}$ & 0.000 & $\mathrm{H}_{0}$ ditolak \\
\hline 3. & Gaya Belajar & 0.003 & $\mathrm{H}_{0}$ ditolak \\
\hline & $\begin{array}{c}\text { Interaksi Media * } \\
\text { Kemampuan Penalaran } \\
\text { Analitis }\end{array}$ & 0.015 & $\mathrm{H}_{0}$ ditolak \\
\hline & $\begin{array}{c}\text { Interaksi Media * Gaya } \\
\text { Belajar }\end{array}$ & 0.550 & $\mathrm{H}_{0}$ diterima \\
\hline & $\begin{array}{c}\text { Interaksi Kemampuan } \\
\text { Penalaran Analitis * } \\
\text { Gaya Belajar }\end{array}$ & 0.039 & $\mathrm{H}_{0}$ ditolak \\
\hline & $\begin{array}{c}\text { Interaksi Media * } \\
\text { Kemampuan Penalaran } \\
\text { Analitis * Gaya Belajar }\end{array}$ & 0.924 & $\mathrm{H}_{0}$ diterima \\
\hline
\end{tabular}

Tabel 2b. Rangkuman Uji Hipotesis Prestasi Belajar

\begin{tabular}{|c|c|c|c|}
\hline \multirow{2}{*}{ No } & \multirow{2}{*}{ Variabel } & \multicolumn{2}{|c|}{ Prestasi Belajar Afektif } \\
\hline & & Sig. & Keputusan Uji \\
\hline 1. & Media & 0.007 & $\mathrm{H}_{0}$ ditolak \\
\hline 2. & $\begin{array}{c}\text { Kemampuan Penalaran } \\
\text { Analitis } \\
\end{array}$ & 0.000 & $\mathrm{H}_{0}$ ditolak \\
\hline 3. & Gaya Belajar & 0.000 & $\mathrm{H}_{0}$ ditolak \\
\hline 4. & $\begin{array}{c}\text { Interaksi Media * } \\
\text { Kemampuan Penalaran } \\
\text { Analitis }\end{array}$ & 0.036 & $\mathrm{H}_{0}$ ditolak \\
\hline 5. & $\begin{array}{c}\text { Interaksi Media * Gaya } \\
\text { Belajar }\end{array}$ & 0.659 & $\mathrm{H}_{0}$ diterima \\
\hline 6. & $\begin{array}{c}\text { Interaksi Kemampuan } \\
\text { Penalaran Analitis * } \\
\text { Gaya Belajar }\end{array}$ & 0.042 & $\mathrm{H}_{0}$ ditolak \\
\hline 7. & $\begin{array}{c}\text { Interaksi Media * } \\
\text { Kemampuan Penalaran } \\
\text { Analitis* Gaya Belajar }\end{array}$ & 0.576 & $\mathrm{H}_{0}$ diterima \\
\hline
\end{tabular}

Berdasarkan Tabel 2a dan 2b, maka dapat dijelaskan dalam pembahasan berikut:

a.Pengaruh media simulasi animasi komputer dan film pendek terhadap prestasi belajar siswa

Suhu dan Kalor merupakan salah satu konsep Fisika yang dipelajari di SMK kelas XI yang meliputi beberapa hal antara lain Suhu, Kalor, Pemuaian, Perubahan Wujud Zat, dan Perpindahan Kalor. Karakteristik materi Suhu 
dan Kalor termasuk materi konkrit. Dalam materi Suhu dan Kalor terdapat konsep-konsep Fisika yang penerapannya ada dalam kehidupan seharihari. Salah satu pendekatan yang sesuai dengan karakteristik materi Suhu dan Kalor adalah pendekatan kontekstual. Melalui pendekatan kontekstual dapat mendorong guru untuk mlenghubungkan antara materi yang diajarkan dan situasi dunia nyata siswa dan mendorong siswa membuat hubungan antara pengetahuan yang dimilikinya dan penerapannya dalam kehidupan mereka sendiri-sendiri sehingga siswa akan memahami lebih banyak persoalan kaitannya dengan materi pembelajarannya dan lebih mudah memahami konsep tentang Suhu dan Kalor.

Dalam pembelajaran untuk mendukung metode yang digunakan guru, juga diperlukan media pembelajaran. Media yang digunakan dalam penelitian ini berupa simulasi animasi komputer dan film pendek dengan maksud agar lebih menarik, dapat merangsang pikiran, perhatian, dan kemauan siswa sehingga dapat mendorong dan mempermudah siswa dalam meningkatkan prestasi belajar siswa. Media simulasi animasi komputer dan film pendek digunakan sebagai panduan siswa dalam melaksanakan kegiatan pembelajaran. Media simulasi animasi komputer dapat menghidupkan suatu obyek yang diperjelas dengan grafis (gambar dan tulisan-tulisan) dan gerakan untuk dapat digunakan secara efektif dalam menyampaikan pesan atau informasi. Gambar dalam media animasi dapat digerakkan dan diatur sedemikian rupa sehingga tampak hidup. Media film pendek berisi video tentang fenomenafenomena dalam kehidupan sehari-hari yang terkait dengan materi Suhu dan Kalor. Video tersebut hanya dapat dilihat saja tetapi tidak bisa diatur dengan sedemikian rupa seperti animasi.

Pada prestasi belajar kognitif ditemukan ada pengaruh penggunaan pendekatan kontekstual melalui media simulasi animasi komputer dan film pendek terhadap prestasi belajar kognitif siswa. Hal ini disebabkan media simulasi animasi komputer dan film pendek yang digunakan berisi fenomena-fenomena kehidupan sehari-hari yang terkait Suhu dan Kalor yang sebagian besar memberikan informasi yang mendukung kemampuan kognitif siswa dalam memahami konsep materi Suhu dan Kalor. Pada prestasi belajar afektif juga ditemukan ada pengaruh penggunaan pendekatan kontekstual melalui media simulasi animasi komputer dan film pendek terhadap prestasi belajar afektif siswa. Hal ini disebabkan dalam pelaksanaan pembelajaran siswa sudah terbiasa dengan penggunaan media pembelajaran seperti animasi maupun film sehingga dapat mendukung kemampuan afektif siswa.

Hal ini sejalan dengan penelitian dari Yuen-kuang Liao (2007) yang menyimpulkan bahwa "CSI (Computer Simulation Instruction) is more effective than TI (Traditional Instruction) in Taiwan." Jadi pada penelitian ini menyatakan bahwa CSI (Computer Simulation Instruction) lebih efektif daripada TI (Traditional Instruction). Pada penelitian ini media yang digunakan adalah simulasi animasi komputer untuk menunjukkan fenomena-fenomena seharihari agar lebih jelas dan menarik.

Berdasarkan uji lanjut terlihat bahwa prestasi belajar kognitif siswa yang diberi perlakuan pembelajaran dengan media simulasi animasi komputer mempunyai rerata yang lebih besar dibanding dengan siswa yang diberi perlakuan pembelajaran dengan media film pendek. Rerata kelas eksperimen I yang diberi perlakuan pembelajaran dengan media simulasi animasi komputer adalah 69,99 sedangkan rerata kelas eksperimen II yang diberi perlakuan pembelajaran dengan media komik adalah 65,98. Dengan demikian, maka dapat disimpulkan bahwa pembelajaran menggunakan pendekatan kontekstual melalui media simulasi animasi komputer yang lebih baik daripada pembelajaran menggunakan pendekatan kontekstual melalui media film pendek pada materi Suhu dan Kalor. Hal ini juga didukung dengan data di lapangan hasil interview dengan siswa bahwa siswa lebih senang belajar menggunakan simulasi animasi komputer daripada film pendek.

b.Pengaruh kemampuan penalaran analitis terhadap prestasi belajar siswa

Kemampuan penalaran analitis merupakan suatu kemampuan kegiatan berpikir yang menyandarkan diri kepada suatu analisis dan kerangkar berpikir dengan logika penalaran. Artinya penalaran ilmiah merupakan kegiatan analisis yang mempergunakan logika ilmiah. Sifat analitik ini merupakan konsekuensi dari suatu pola berpikir tertentu. Kemampuan penalaran analitis memiliki kelebihan dapat mengukur kemampuan peserta didik dalam membaca, mencerna, menganalisis dan menarik 
kesimpulan terhadap informasi yang telah disampaikan.

Pada prestasi belajar kognitif ditemukan ada pengaruh kemampuan penalaran analitis siswa terhadap prestasi belajar kognitif siswa. Hal ini disebabkan prestasi belajar kognitif siswa diambil dari nilai hasil tes pretasi belajar kognitif siswa pada materi Suhu dan Kalor. Soal dan pilihan jawaban pada tes prestasi belajar kognitif ada yang memerlukan logika penalaran dan analisis. Jadi untuk menjawab pertanyaan pada soal tes prestasi belajar kognitif diperlukan kemampuan penalaran analitis siswa yang baik agar siswa mudah memahami dan menganalisis maksud soal dan pilihan jawaban. Pada prestasi belajar afektif juga ditemukan ada pengaruh kemampuan penalaran analitis siswa terhadap prestasi belajar afektif siswa. Hal ini dikarenakan instrumen penilaian prestasi afektif siswa sebagian besar mencakup kemampuan penalaran analitis siswa dan siswa melakukan kegiatan sesuai indikator dalam instrumen tersebut.

Hal ini sejalan dengan penelitian yang dilakukan oleh Murwani Dewi Wijayanti (2009) tentang kemampuan penalaran analitis. Pada penelitian tersebut menyimpulkan bahwa media modul berbasis IT pada model pembelajaran individual lebih sesuai untuk prestasi belajar peserta didik yang memiliki daya kemampuan penalaran analitis tinggi dibandingkan kemampuan penalaran analitis rendah. Hal ini menunjukkan bahwa kemampuan penalaran analitis dapat mempengaruhi prestasi belajar siswa.

Berdasarkan uji lanjut terlihat bahwa baik untuk prestasi belajar kognitif maupun afektif, siswa yang berkemampuan penalaran analitis tinggi mempunyai rerata yang lebih besar dibanding dengan siswa yang berkemampuan penalaran analitis rendah. Rerata prestasi belajar kognitif dan afektif siswa yang berkemampuan penalaran analitis tinggi secara berturut-turut adalah 72,86 dan 76,31 sedangkan rerata prestasi belajar kognitif dan afektif siswa yang berkemampuan penalaran analitis rendah secara berturut-turut adalah 63,11 dan 63,76. Dengan demikian, maka dapat disimpulkan bahwa siswa yang mempunyai kemampuan penalaran analitis tinggi memperoleh prestasi belajar baik prestasi belajar kognitif maupun afektif yang lebih baik dibandingkan dengan siswa yang mempunyai kemampuan penalaran analitis rendah. Dengan kata lain, semakin tinggi kemampuan penalaran analitis siswa maka makin tinggi pula prestasi belajar yang dicapai, sebaliknya semakin rendah kemampuan penalaran analitis siswa maka makin rendah pula prestasi belajar yang dicapai.

c. Pengaruh gaya belajar siswa terhadap prestasi belajar siswa

"Gaya belajar adalah kombinasi dari bagaimana seseorang menyerap dan kemudian mengatur serta mengolah informasi". (Bobbi DePorter, 2008: 112-113). Dari kutipan tersebut gaya belajar dapat diartikan sebagai kecenderungan seseorang untuk mengolah dan menerima informasi. Siswa memiliki gaya belajar yang berbeda-beda diantaranya gaya belajar visual, auditorial, dan kinestetik.

Namun dalam penelitian ini yang digunakan hanya dua gaya belajar yaitu kinestetik dan visual. Gaya belajar visual ditandai dengan melihat dulu buktinya untuk kemudian bisa mempercayainya. Siswa yang memiliki gaya belajar visual harus melihat dulu baru kemudian bisa mengingat dan memahami informasi (materi pelajaran). Gaya belajar kinestetik, siswa harus menyentuh sesuatu yang memberikan informasi tertentu agar siswa bisa mengingatnya. Siswa bisa belajar lebih baik apabila disertai dengan kegiatan fisik.

Pada prestasi belajar kognitif ditemukan ada pengaruh gaya belajar siswa terhadap prestasi belajar kognitif siswa. Hal ini dikarenakan prestasi belajar kognitif siswa diambil dari nilai hasil tes pretasi belajar kognitif siswa pada materi Suhu dan Kalor. Siswa yang mempunyai gaya belajar visual pasti sangat cermat dalam mengerjakan tes prestasi belajar kognitif sehingga hasilnya menjadi baik. Siswa yang mempunyai gaya belajar kinestetik ada pengaruh gaya belajar siswa terhadap prestasi belajar kognitif dikarenakan pada saat tes prestasi belajar kognitif suasananya dibuat santai dan tidak kaku sehingga mereka bebas melakukan gerakangerakan yang mereka sukai.

Hal ini sejalan dengan penelitian yang dilakukan oleh Basir (2010) yang berkaitan dengan gaya belajar. Pada penelitian tersebut menyimpulkan bahwa gaya belajar merupakan variabel penting yang perlu dipertimbangkan dalam proses pembelajaran untuk meningkatkan prestasi belajar siswa. Hal ini menunjukkan bahwa gaya belajar sangat mempengaruhi meningkatnya prestasi belajar siswa.

Pada prestasi belajar afektif ditemukan ada pengaruh gaya belajar siswa terhadap prestasi 
belajar afektif siswa. Hal ini dikarenakan semua siswa melakukan kegiatan sesuai indikator dalam instrumen penilaian afektif dengan baik karena siswa sudah dibiasakan untuk selalu mengikuti dan memperhatikan instruksi dari guru.

Berdasarkan uji lanjut terlihat bahwa baik untuk prestasi belajar kognitif maupun afektif, siswa dengan gaya belajar visual mempunyai rerata yang lebih besar dibanding dengan siswa dengan gaya belajar kinestetik. Rerata prestasi belajar kognitif dan afektif siswa dengan gaya belajar visual secara berturut-turut adalah 69,88 dan 74,21 sedangkan rerata prestasi belajar kognitif dan afektif siswa dengan gaya belajar kinestetik secara berturut-turut adalah 66,10 dan 65,86. Dengan demikian, maka dapat disimpulkan bahwa siswa dengan gaya belajar visual memperoleh prestasi belajar baik prestasi belajar kognitif maupun afektif yang lebih baik dibandingkan dengan siswa dengan gaya belajar kinestetik.

d.Interaksi media simulasi animasi komputer dan

film pendek dan kemampuan penalaran analitis terhadap prestasi belajar siswa

Pada prestasi belajar afektif, ditemukan pengaruh bersama yang signifikan antara media pembelajaran dengan kemampuan penalaran analitis siswa terhadap prestasi belajar afektif siswa. Hal ini karena prestasi belajar afektif berkaitan dengan kemampuan bersikap peserta didik dalam mengikuti pembelajaran. Sikap peserta didik dalam pembelajaran dapat berupa sikap menerima, menghargai dan menanggapi pendapat atau pertanyaan baik dari guru maupun teman, sikap mengatur diri (mengorganisasi diri) dalam bekerja kelompok, serta kemampuan berkomunikasi siswa. Sikap-sikap tersebut dapat muncul apabila didukung dengan kemampuan penalaran analitis siswa yang baik dan media pembelajaran yang tepat pula. Hal ini karena penggunaan pendekatan kontekstual melalui media simulasi animasi komputer ditinjau dari kemampuan penalaran analitis siswa yang menitikberatkan pada kemampuan berpikir yang menyandarkan diri kepada suatu analisis dan kerangkar berpikir dengan logika penalaran

Hal ini sejalan dengan penelitian yang dilakukan oleh Murwani Dewi Wijayanti (2009) tentang interaksi antara media pembelajaran dengan kemampuan penalaran analitis. Pada penelitian tersebut menyimpulkan bahwa media modul berbasis IT pada model pembelajaran individual lebih sesuai untuk prestasi belajar peserta didik yang memiliki daya kemampuan penalaran analitis tinggi dibandingkan kemampuan penalaran analitis rendah. Hal ini menunjukkan adanya interaksi antara media pembelajaran modul berbasi IT dengan kemampuan penalaran analitis.

e. Interaksi media simulasi animasi komputer dan film pendek dan gaya belajar siswa terhadap prestasi belajar siswa

Pada prestasi belajar kognitif dan afektif tidak ditemukan pengaruh bersama yang signifikan antara media pembelajaran dengan gaya belajar siswa terhadap prestasi belajar kognitif dan afektif siswa. Pengaruh yang diberikan media simulasi animasi komputer dan film pendek terhadap prestasi belajar kognitif dan afektif siswa merupakan pengaruh yang berdiri sendiri dan tidak berhubungan dengan gaya belajar siswa. Begitu pula sebaliknya, pengaruh yang diberikan gaya belajar siswa terhadap prestasi belajar kognitif dan afektif merupakan pengaruh yang berdiri sendiri dan tidak berhubungan dengan media simulasi animasi dan film pendek.

Kelompok siswa yang diberi pembelajaran menggunakan media simulasi animasi komputer, antara siswa yang mempunyai gaya belajar visual dan kinestetik tidak menunjukkan adanya perbedaan prestasi belajar kognitif dan afektif yang signifikan. Hal yang sama juga terjadi pada kelompok siswa yang diberi pembelajaran menggunakan media film pendek, antara siswa yang mempunyai gaya belajar visual dan kinestetik tidak menunjukkan adanya perbedaan prestasi belajar kognitif dan afektif yang signifikan. Hal ini karena keberhasilan belajar mengajar dipengaruhi oleh beberapa faktor, baik faktor internal maupun faktor eksternal siswa. Faktor-faktor tersebut tidak sepenuhnya dapat diperhatikan dan dikontrol oleh guru. Selain itu siswa tidak hanya belajar di sekolah saja tetapi dapat juga belajar di luar sekolah. Sebagai contoh, meskipun diberi pembelajaran dengan media yang sama, siswa yang mempunyai gaya belajar visual karena mengikuti les privat, suka membaca buku, suka memperhatikan dan mendengarkan pelajaran, aktif bertanya kepada guru dan teman, serta aktif dalam kegiatan praktikum maka prestasi belajar kognitif dan afektif dimungkinkan sama dengan siswa yang mempunyai gaya belajar kinestetik. Oleh karena itu siswa yang memiliki gaya belajar berbeda (visual dan kinestetik), meskipun diberi 
pembelajaran dengan media yang sama tidak memberikan pengaruh yang signifikan terhadap prestasi belajar kognitif dan afektif siswa.

Demikian juga untuk kelompok siswa dengan gaya belajar visual, jika diberi perlakuan pembelajaran menggunakan media simulasi animasi komputer dan film pendek akan memberikan pengaruh yang sama terhadap prestasi belajar kognitif dan afektif siswa. Kelompok siswa dengan gaya belajar kinestetik, jika diberi perlakuan pembelajaran menggunakan simulasi animasi komputer dan film pendek juga memberikan pengaruh yang sama terhadap prestasi belajar kognitif dan afektif siswa. Hal ini disebabkan baik dalam media simulasi animasi komputer dan film pendek berisi gambar dan tulisan yang hampir sama, yang sama-sama mendukung siswa yang bergaya belajar visual. Selain itu baik dalam media simulasi animasi komputer dan film pendek pembelajaran samasama dilakukan dengan menggunakan metode diskusi yang sama-sama membebaskan siswa untuk bergerak dan sesuai dengan gaya belajar kinestetik. Oleh karena itu antara siswa yang memiliki gaya belajar sama, jika diberi pembelajaran dengan media yang berbeda tidak memberikan pengaruh yang signifikan terhadap prestasi belajar kognitif, afektif, dan psikomotorik siswa.

Pada prestasi belajar kognitif dan afektif, dua variabel bebas tersebut yaitu media pembelajaran dan gaya belajar tidak menghasilkan kombinasi efek yang signifikan. Oleh karena itu dapat disimpulkan tidak ada interaksi antara penggunaan pendekatan kontekstual melalui media simulasi animasi dan film pendek dan gaya belajar siswa terhadap prestasi belajar siswa baik prestasi belajar kognitif maupun afektif siswa.

Meskipun tidak ada interaksi antara penggunaan pendekatan kontekstual melalui media simulasi animasi dan film pendek dan gaya belajar siswa terhadap prestasi belajar siswa baik prestasi belajar kognitif maupun afektif siswa, namun berdasarkan penelitian dari Murwani Dewi Wijayanti (2009) menyimpulkan bahwa prestasi belajar kimia hasil dari penerapan model pembelajaran individual dengan media modul berbasis IT lebih sesuai daripada penerapan model pembelajaran individual dengan media simulasi animasi komputer. Dan penelitian Murat Peker dan Seref Mirasyedioglu (2007) menyimpulkan bahwa "one of the factors which affect the attitudes towards mathematics is learning styles." Berdasarkan penelitian tersebut menunjukkan bahwa gaya belajar adalah salah satu faktor yang mempengaruhi sikap terhadap matematika. Pada penelitian tersebut diketahui bahwa ada pengaruh gaya belajar terhadap prestasi belajar siswa.

f. Interaksi kemampuan penalaran analitis dan gaya belajar siswa terhadap prestasi belajar siswa

Siswa memiliki kecenderungan dalam menerima dan mengolah informasi selama proses pembelajaran berlangsung sesuai dengan gaya belajar mereka masing-masing yaitu visual maupun kinestetik. Siswa juga memiliki kemampuan penalaran analitis yang berbedabeda. Untuk dapat berpikir yang dengan logika penalaran dan analisis diperlukan kemampuan penalaran analitis siswa. Siswa yang memiliki kemampuan penalaran analitis tinggi dan didukung dengan gaya belajar siswa yang tepat akan memperoleh prestasi belajar yang lebih baik.

Pada prestasi belajar kognitif dan afektif, ditemukan pengaruh bersama yang signifikan antara kemampuan penalaran analitis dengan gaya belajar siswa terhadap prestasi belajar kognitif dan afektif siswa. Dengan kemampuan penalaran analitis yang baik, siswa dapat berpikir yang dengan logika penalaran dan analisis. Pembelajaran yang dilakukan dengan memperhatikan gaya belajar siswa akan menghasilkan prestasi belajar yang baik. Sebagai contoh, siswa yang mempunyai gaya belajar visual, dengan melihat media (simulasi animasi komputer dan film pendek) dan membaca buku, dapat menggunakan logikanya untuk menganalisis materi yang dipelajari dalam kegiatan diskusi, dapat menjawab pertanyaan guru atau teman serta bertanya kepada guru atau teman yang belum dimengerti. Siswa yang mempunyai gaya belajar kinestetik, dengan melakukan praktikum juga dapat menggunakan logikanya untuk menganalisis masalah dalam diskusi, dapat menjawab pertanyaan guru atau teman serta bertanya kepada guru atau teman yang belum dimengerti. Oleh karena itu siswa yang memiliki kemampuan penalaran analitis tinggi dan didukung dengan gaya belajar siswa yang tepat akan memperoleh prestasi belajar yang lebih baik.

Berdasarkan hasil pengujian hipotesis untuk prestasi belajar kognitif menunjukkan 
adanya interaksi antara kemampuan penalaran analitis dan gaya belajar siswa terhadap prestasi belajar kognitif siswa. Hal ini sejalan dengan penelitian yang dilakukan oleh Murwani Dewi Wijayanti (2009) menyimpulkan bahwa media modul berbasis IT pada model pembelajaran individual lebih sesuai untuk prestasi belajar peserta didik yang memiliki daya kemampuan penalaran analitis tinggi dibandingkan kemampuan penalaran analitis rendah. Pada penelitian tersebut menunjukkan bahwa ada pengaruh kemampuan penalaran analitis terhadap prestasi belajar siswa. Dan penelitian yang dilakukan oleh Basir (2010) menyimpulkan bahwa gaya belajar merupakan variabel penting yang perlu dipertimbangkan dalam proses pembelajaran untuk meningkatkan prestasi belajar siswa. Pada penelitian tersebut menunjukkan ada pengaruh gaya belajar terhadap prestasi belajar siswa.

g. Interaksi media simulasi animasi computer dan film pendek, kemampuan penalaran analitis, dan gaya belajar siswa terhadap prestasi belajar siswa

Pada prestasi belajar kognitif dan afektif, tidak ditemukan pengaruh bersama yang signifikan antara media, kemampuan penalaran analitis, dan gaya belajar siswa terhadap prestasi belajar kognitif dan afektif. Siswa yang diberi pembelajaran menggunakan media simulasi animasi komputer memiliki rata-rata yang lebih baik daripada siswa yang diberi pembelajaran menggunakan media film pendek, siswa dengan kemampuan penalaran analitis tinggi memiliki rata-rata lebih baik daripada siswa dengan kemampuan penalaran analitis rendah, siswa dengan gaya belajar yang tepat memiliki rata-rata lebih baik. Hal tersebut karena keberhasilan belajar mengajar dipengaruhi oleh beberapa faktor, baik faktor internal maupun faktor eksternal siswa. Faktor-faktor tersebut tidak sepenuhnya dapat diperhatikan dan dikontrol oleh guru. Selain itu siswa tidak hanya belajar di sekolah saja tetapi dapat juga belajar di luar sekolah.

Meskipun tidak ada pengaruh bersama yang signifikan antara media, kemampuan penalaran analitis, dan gaya belajar siswa terhadap prestasi belajar kognitif dan afektif, namun berdasarkan penelitian dari Yuen-kuang Liao (2007) menyimpulkan bahwa "CSI (Computer Simulation Instruction) is more effective than TI (Traditional Instruction) in
Taiwan." Jadi pada penelitian ini menyatakan bahwa CSI (Computer Simulation Instruction) lebih efektif daripada TI (Traditional Instruction). Dari penelitian tersebut dapat diketahui bahwa ada pengaruh media pembelajaran terhadap prestasi belajar siswa. Dan penelitian dari Murwani Dewi Wijayanti (2009) menyimpulkan bahwa media modul berbasis IT pada model pembelajaran individual lebih sesuai untuk prestasi belajar peserta didik yang memiliki daya kemampuan penalaran analitis tinggi dibandingkan kemampuan penalaran analitis rendah. Pada penelitian tersebut dapat diketahui bahwa ada pengaruh kemampuan penalaran analitis terhadap prestasi belajar siswa. Selain itu penelitian dari Murat Peker dan Seref Mirasyedioglu (2007) menyimpulkan bahwa "one of the factors which affect the attitudes towards mathematics is learning styles." Berdasarkan penelitian tersebut menunjukkan bahwa gaya belajar adalah salah satu faktor yang mempengaruhi sikap terhadap matematika. Hal ini menunjukkan bahwa ada pengaruh gaya belajar terhadap prestasi belajar siswa.

\section{Kesimpulan Dan Rekomendasi}

Hasil penelitian ini dapat diambil kesimpulan adalah

1. Ada pengaruh penggunaan pendekatan kontekstual melalui media simulasi animasi komputer dan film pendek terhadap prestasi belajar siswa.

2. Ada pengaruh kemampuan penalaran analitis kategori tinggi dan rendah terhadap prestasi belajar siswa.

3. Ada pengaruh gaya belajar siswa kategori visual dan kinestetik terhadap prestasi belajar siswa.

4. Ada interaksi antara penggunaan pendektan kontekstual melalui media simulasi animasi komputer dan film pendek dengan kemampuan penalaran analitis terhadap prestasi belajar siswa.

5. Tidak ada interaksi antara penggunaan pendektan kontekstual melalui media simulasi animasi komputer dan film pendek dengan gaya belajar siswa terhadap prestasi belajar siswa.

6. Ada interaksi antara kemampuan penalaran analitis dan gaya belajar siswa terhadap prestasi belajar siswa. 
7. Tidak ada interaksi antara penggunaan pendekatan kontekstual melalui media simulasi animasi komputer dan film pendek, kemampuan penalaran analitis dan gaya belajar siswa terhadap prestasi belajar siswa

Rekomendasi dari hasil penelitian yang telah dilakukan adalah

1. Guru sebaiknya menggunakan pendekatan kontekstual melalui media simulasi animasi komputer dalam melaksanakan pembelajaran Fisika khususnya pada materi Suhu dan Kalor, dalam hal ini guru sebagai fasilitator dan siswa secara aktif terlibat dalam proses belajar mandiri.

2. Dalam pembelajaran menggunakan media, guru sebaiknya mempersiapkan strategi dan perlengkapan yang diperlukan seperti media pembelajaran dalam bentuk simulasi animasi, LKS, dan fasilitas pendukung (LCD dan laptop/komputer) agar proses pembelajaran dapat berlangsung dengan lancar dan sesuai dengan tujuan yang diharapkan.

3. Dalam skenario pembelajaran guru sebaiknya memperhatikan gaya belajar siswa karena setiap siswa memiliki gaya belajar yang berbeda-beda diantaranya gaya belajar visual, auditorial, dan kinestetik sehingga dapat tepat menggunakan pembelajarn yang sesuai dengan gaya belajar siswa.

4. Selain gaya belajar siswa ada faktor yang juga sangat mempengaruhi prestasi belajar siswa yaitu kemampuan penalaran analitis. Guru juga harus memperhatikan kemampuan analitis siswa yaitu dengan melatih siswa mengerjakan soal-soal tentang logika penalaran analitis dan memberikan masalah agar dipecahkan dengan logika penalaran analitis.

\section{DAFTAR PUSTAKA}

Azhar Arsyad. (2002). Media Pembelajaran. Jakarta: Rajawali Press

Basir. (2009). Pembelajaran Fisika Dengan Metode Inkuiri Terbimbing Menggunakan Virtualab dan Realab Ditinjau Dari Gaya Belajar dan Gaya Berpikir Siswa. Surakarta: Tesis Program Pendidikan Sains Program Pascasarjana Universitas Sebelas Maret.
DePotter, Bobby \& Mike Hernacki. (1999). Quantum Learning : Membiasakan Belajar Nyaman dan Menyenangkan (diterjemahkan oleh Alwiyah Abdurrahman). Bandung: Kaifa

Dimyati \& Mudjiono. (2009). Belajar dan Pembelajaran. Jakarta: Rineka Cipta

J.J Hasibuan \& Moedjiono. (2006). Proses Belajar Mengajar. Bandung: PT Remaja Rosdakarya

Kokom Komalasari. (2009). The Effect of Contextual Learning in Civic Education on Students' Civic Competence. Malaysia: Asia Pasific Journal of Educators and Education.

Kuang Liao, Yuen. (2007). The Effect of Computer Simulation Instruction on Student Learning: Meta-analysis of Studies in Taiwan. Taiwan: Eurasia Journal of Mathematics, Science, and Technology Education.

Murwani Dewi Wijayanti. (2009). Kesesuaian Penggunaan Media Modul Berbasis IT dan Simulasi Animasi Komputer pada Model Pembelajaran Individual Ditinjau dari Kemampuan Awal dan Kemampuan Penalaran Analitis. Surakarta: Tesis Program Pendidikan Sains Program Pascasarjana Universitas Sebelas Maret

Peker, Murat \& Seref Mirasyedioglu. (2007). PreService Elementary School Teachers' Learning Styles and Attitudes towards Mathematics. Turki: Eurasia Journal of Mathematics, Science, and Technology Education.

Sri Anitah. (2008). Media Pembelajaran. Surakarta: UNS Press

Sugiyanto. (2007). Modul Pendidikan dan Latihan Profesi Guru (PLPG): Model-model Pembelajaran Inovatif. Surakarta: Panitia Sertifikasi Guru Rayon 13

Teguh Ernawan. (2010). Pembelajaran IPA Melalui Metode Demonstrasi Menggunakan Media Animasi dan 2 Dimensi Ditinjau Dari Kemampuan Tingkat Berpikir dan Gaya Belajar Siswa. Surakarta: Tesis Program Pascasarjana Universitas Sebelas Maret Surakarta

Widha Sunarno. (2008). Paedagogia Jurnal Penelitian Pendidikan. Surakarta: UNS Press

Widodo. (2009). Pembelajaran Kimia dengan Pendekatan Kontekstual melalui Metode Eksperimen dan Demonstrasi Ditinjau dari Kreativitas dan Sikap Ilmiah Siswa. Surakarta: Tesis Program Pasacasarjana Universitas Sebelas Maret Surakarta.

www.timss.bc.edu/timss2007/idb_ug.html. 